\title{
Application of the total etching technique or self-etching primers on primary teeth after air abrasion
}

\section{Aplicação da técnica de condicionamento total ou de "primers" autocondicionantes em dentes decíduos após abrasão a ar}

Fábio Renato Manzolli Leite*

Ticiana Sidorenko de Oliveira Capote**

Angela Cristina Cilense Zuanon**

\begin{abstract}
Since the use of air abrasion has grown in pediatric dentistry, the aim of this study was to evaluate, by means of shear bond strength testing, the need to use the total etching technique or self-etching primers on dentin of primary teeth after air abrasion. Twenty-five exfoliated primary molars had their occlusal dentin exposed by trimming and polishing. Specimens were treated by: Air abrasion + Scotchbond MultiPurpose adhesive (G1); 37\% phosphoric acid + Scotchbond MP adhesive (G2); Clearfil SE (G3); Air abrasion + 37\% phosphoric acid + Scotchbond MP adhesive (G4); Air abrasion + Clearfil SE (G5). On the treated surface, a cylinder of $2 \mathrm{~mm}$ by $6 \mathrm{~mm}$ was made using a composite resin (Z100). Duncan's test showed that: $(\mathrm{G} 2=\mathrm{G} 3=\mathrm{G} 5)>(\mathrm{G} 1=\mathrm{G} 4)$. The use of a selfetching primer on air abraded dentin is recommended to obtain higher bond strengths.
\end{abstract}

DESCRIPTORS: Air abrasion, dental; Tooth, deciduous; Dentin; Dentin-bonding agents; Acid etching, dental.

\begin{abstract}
RESUMO: Como o uso da abrasão a ar tem aumentado em odontopediatria, o objetivo deste trabalho foi avaliar a resistência ao cisalhamento da resina composta Z100 sobre a superficie dentinária de dentes decíduos após abrasionamento a ar associado ou não a técnica de condicionamento total (ácido fosfórico + Scotchbond Multi Purpose) ou "primer" autocondicionante (Clearfil SE Bond). A superfície oclusal de 25 molares decíduos foi removida para exposição completa da superficie dentinária. Após polimento com lixas abrasivas, foram divididos em 5 grupos (5 espécimes em cada) tratados por abrasão + adesivo Scotchbond (G1); condicionamento ácido + adesivo Scotchbond (G2); adesivo Clearfil (G3); abrasão a ar + condicionamento ácido + adesivo Scotchbond (G4); abrasão a ar + adesivo Clearfil (G5). Uma matriz bipartida foi adaptada à superficie dentinária e preenchida com resina composta. Após polimerização, corpos-de-prova de $2 \mathrm{~mm}$ x $6 \mathrm{~mm}$ foram obtidos. O teste de Duncan mostrou a desigualdade $(\mathrm{G} 1=\mathrm{G} 4)<(\mathrm{G} 2=\mathrm{G} 3=\mathrm{G} 5)$. Desse modo, conclui-se que, após o abrasionamento dentinário, deve ser utilizado o sistema de "primer" autocondicionante a fim de se obter maior força de adesão.

DESCRITORES: Abrasão dental por ar; Dente decíduo; Dentina; Adesivos dentinários; Condicionamento ácido dentário.
\end{abstract}

\section{INTRODUCTION}

The use of conservative cavity design has been made possible due to advances in techniques and restorative materials resulting in adhesive restorations. An effective way to improve bond strength was obtained with the use of the $85 \%$ phosphoric acid technique suggested by Buonocore ${ }^{3}$ in 1955.

Years latter, the acid concentration was reduced, and many studies were developed to create bonding agents that could increase the interaction between dentin and restorative materials. To promote satisfactory adhesion, superficial smear layer must be removed and subjacent dentin must be slightly demineralized ${ }^{16}$. Although acid conditioning can remove the smear layer and dentine mineral, which increases the bond strength, it may cause collagen fiber destabilization, diminishing bond strength when incorrectly used.

In pediatric dentistry, the use of air abrasion in caries lesions has increased. Some studies suggest the use of air abrasion as a possible way to substitute acid etching and also to increase adhesion of restorative materials because this technique is based on high speed aluminum oxide im-

\footnotetext{
* MS, Department of Diagnosis and Surgery; **PhDs, Department of Pediatric Dentistry - School of Dentistry of Araraquara, São Paulo State University.
} 
Leite FRM, Capote TSO, Zuanon ACC. Application of the total etching technique or self-etching primers on primary teeth after air abrasion. Braz Oral Res 2005;19(3):198-202.

pact against teeth to remove mineral structure ${ }^{7,15}$. Some advantages of air abrasion over the rotary system are the reduction in or elimination of pain, vibration, pressure, heating and noise $\mathrm{e}^{1,8,13}$.

Some studies have suggested the use of air abrasion to obtain composite retention ${ }^{11}$. In SEM analysis, the same authors observed that the enamel surface roughness was high, and Goldstein, Parkins ${ }^{7}$ (1994) suggested the use of air abrasion to prepare enamel and dentin with similar adhesive force when compared with that promoted by acid etching.

Some authors have stated that air abrasion does not eliminate the need for acid etching, and that they could observe an increase in forces when both techniques were associated ${ }^{2,25}$. According to Hannig, Femerling ${ }^{10}$ (1998), adhesive systems need to be applied after air abrasion for best adhesion and dentin gap reduction.

This study aimed to evaluate the need to use the total etching technique or self-etching primers on primary teeth dentin after air abrasion.

\section{MATERIALS AND METHODS}

This study was approved by the Human Research Ethics Committee, School of Dentistry of Araraquara, São Paulo State University. Twentyfive caries-free primary molars were collected after exfoliation and maintained under refrigeration in $1 \%$ thymol solution (J. T. Baker, Phillipsburg, New Jersey, USA) for one month. The teeth had their root and occlusal surfaces removed perpendicularly to the long axis by means of a precision trimmer machine under water irrigation (ISOMET 1000, Buehler Lux Ltd., Illinois, USA).

Samples were embedded in chemically activated acrylic resin (OrtoClass, Artigos Odontológicos Clássico, Campo Limpo Paulista, SP, Brazil) inside PVC cylinders (Tigre, Joinville, Santa Catarina, Brazil). Complete and uniform dentin exposure was created using abrasive paper \#1200 (Norton,
Guarulhos, São Paulo, Brazil) for polishing under $600 \mathrm{rpm}$ using water refrigeration (Metaserv 2000, Buehler Lux Ltd., Illinois, USA), followed by pumice stone (Brainerd, Oklahoma, USA) and water prophylaxis. The composition and manufacturers of the adhesive systems are listed in Table 1. Teeth were randomly assigned to five test groups, as described in Table 2.

The air abrasion system was held by a fixed apparatus to avoid movements, and four millimeters were left between the tip of the equipment and the dentin surface.

After dentin treatment, as seen in Tables 2 and 3 , teeth were adapted to a bipartite metallic matrix (Senai, Araraquara, São Paulo, Brazil) in order to obtain cylindrical composite specimens with $2 \mathrm{~mm}$ in diameter and $6 \mathrm{~mm}$ in height. The matrix was filled with resin composite in three increments and light cured for 40 seconds for each layer. Specimens were positioned in a testing machine with a blunt edge probe (MTS 810, MTS Co., Eden Prairie, MN, USA) for shear bond strength determination at $0.5 \mathrm{~mm} / \mathrm{min}$ crosshead speed.

\section{RESULTS}

The analysis of variance showed that the five treatments produced distinct effects $(p=0.0002)$. After Duncan's test, no differences were found between groups 1 and 4, and groups 2, 3 and 5, but the last three had significantly better results than the first two. Table 4 shows the mean scores obtained in shear bond testing and Duncan's test results.

\section{DISCUSSION}

Interaction of factors just like resin tags, adhesive lateral branches, hybrid layer formation and collagen resistance are essential mechanisms to increase composite bonding to dental structures. These micromechanical principles are achieved

TABLE 1 - Adhesive systems' composition and manufacturers' instructions.

\begin{tabular}{l|l|c|c}
\hline \hline \multicolumn{1}{|c|}{ Adhesive systems } & \multicolumn{1}{|c}{ Composition } & Bonding Instruction* & Manufacturer \\
\hline $\begin{array}{l}\text { Clearfil SE Bond } \\
\text { Adhesive }\end{array}$ & $\begin{array}{l}\text { MDP, Bis-GMA, HEMA, hydrophobic aliphatic } \\
\text { dimethacrylate, } n, n \text { Diethanol-p-Toluidine }\end{array}$ & e, d, f (10 s) & $\begin{array}{l}\text { Kuraray Co. Ltd., } \\
\text { Tokyo, Japan }\end{array}$ \\
\hline $\begin{array}{l}\text { Scotchbond Multi- } \\
\begin{array}{l}\text { Purpose Dental } \\
\text { Adhesive System }\end{array}\end{array}$ & $\begin{array}{l}\text { HEMA, Bis-GMA, polyalkenoic acid, } \\
\text { photoinitiator system }\end{array}$ & a, b, c, d, e, f & $\begin{array}{l}\text { 3M Dental Products } \\
\text { Division, St. Paul, } \\
\text { MN, USA }\end{array}$ \\
\hline \hline
\end{tabular}

Abbreviations: MDP: 10-methacryloyloxy methacrylate; Bis-GMA: bisphenol-A-glycidylmethacrylate; HEMA: hydroxyethyl methacrylate.

*Bonding procedures: (a) acid, (b) water wash, (c) primer, (d) mild air flow, (e) adhesive, (f) light cure. 
Leite FRM, Capote TSO, Zuanon ACC. Application of the total etching technique or self-etching primers on primary teeth after air abrasion. Braz Oral Res 2005;19(3):198-202.

TABLE 2 - Experimental groups according to the dentin treatment.

\begin{tabular}{c|l}
\hline \hline Groups & \multicolumn{1}{c}{ Treatment } \\
\hline 1 & $\begin{array}{l}\text { Air abrasion + Scotchbond Multi-Purpose } \\
\text { Plus + resin composite }\end{array}$ \\
\hline 2 & $\begin{array}{l}\text { 37\% phosphoric acid + Scotchbond Multi- } \\
\text { Purpose Plus + resin composite }\end{array}$ \\
\hline 3 & Clearfil SE Bond + resin composite \\
\hline 4 & $\begin{array}{l}\text { Air abrasion + 37\% phosphoric } \\
\text { acid + Scotchbond Multi-Purpose } \\
\text { Plus + resin composite }\end{array}$ \\
\hline 5 & $\begin{array}{l}\text { Air abrasion + Clearfil SE Bond + resin } \\
\text { composite }\end{array}$ \\
\hline \hline
\end{tabular}

using different techniques such as acid decalcification, air abrasion and the use of adhesive systems $s^{6,9,22}$.

Dentin surface must be prepared for adhesive systems' penetration and impregnation in periand intertubular dentin and flow through tubules and their lateral ramifications ${ }^{6}$. The flow of the adhesive through dentin tubules is determined by the amount of BIS-GMA present in its formula ${ }^{22}$.

Resin tags and hybrid layer formation depend on the adhesive system used, orientation of tubules, dentin surface characteristics, presence and density of tubular ramifications and other in vivo conditions. Also, dentin depth in relation to the pulp determines tubular density and intertubular dentin mineral amount ${ }^{26}$.

Self-etching adhesives penetrate through the smear layer, not removing it completely, fixing smear plugs at the entrance of the tubules ${ }^{22}$. Hybrid layer and resin tags formed with self-etching primers are morphologically comparable in vivo and in vitro when the substrate is kept humid, showing bond strengths similar to the total-etching technique ${ }^{6}$. This data was confirmed in our study, since the groups in which the self-etching primer (G3 and G5) was used had higher adhesive strength.

After comparing the conditioning pattern that resulted from the use of phosphoric acid and aluminum oxide spray on bovine tooth, some authors found that the first one produced regular demineralization $( \pm 6 \mu \mathrm{m})$, while the abraded group presented a rough and irregular surface with peak differences between 4 and $15 \mu \mathrm{m}^{4}$. These authors recommended the use of air abrasion because it was able to increase the surface area and probably produce longer tags. On the other hand, air abrasion removes organic and inorganic matrices,
TABLE 3 - Brand names, manufacturers and dentin treatment techniques.

\begin{tabular}{l|l}
\hline \hline \multicolumn{1}{c|}{ Material } & \multicolumn{1}{c}{ Technique } \\
\hline $\begin{array}{l}\text { 37\% phosphoric acid } \\
\text { (3M Dental Products, St. } \\
\text { Paul, MN, USA) }\end{array}$ & $\begin{array}{l}15 \text { seconds, water wash } \\
\text { and air dry }\end{array}$ \\
\hline $\begin{array}{l}\text { Prep Star (Air abrasion } \\
\text { system) } \\
\text { (Danville Engineering, } \\
\text { San Ramon, CA, USA) }\end{array}$ & $\begin{array}{l}27 \mu \text { m particles, 15 } \\
\text { seconds, 80 psi, water } \\
\text { wash and air dry }\end{array}$ \\
\hline $\begin{array}{l}\text { Z 100 Resin Composite } \\
\text { (3M Dental Products, St. } \\
\text { Paul, MN, USA) }\end{array}$ & $\begin{array}{l}\text { 2 mm increments, 40 } \\
\text { seconds for light curing } \\
\text { each layer }\end{array}$ \\
\hline \hline
\end{tabular}

TABLE 4 - Mean shear bond strength (MPa) significant difference.

\begin{tabular}{c|r|c|c|c|c}
\hline \hline \multirow{2}{*}{ Group } & \multirow{2}{*}{ Mean } & \multicolumn{4}{|c}{ Group } \\
\cline { 3 - 6 } & & G1 & G2 & G3 & G4 \\
\hline G1 & 6.7 & & & & \\
\hline G2 & 18.1 & $0.006^{*}$ & & & \\
\hline G3 & 21.5 & $0.001^{*}$ & 0.348 & & \\
\hline G4 & 9.8 & 0.389 & $0.031^{*}$ & $0.005^{*}$ & \\
\hline G5 & 25.3 & $<0.001^{*}$ & 0.072 & 0.309 & $<0.001^{*}$ \\
\hline \hline
\end{tabular}

*Statistically significant at $\mathrm{p}<0.05$.

causing irreversible tooth structure $\operatorname{loss}^{20}$. Olsen et $a .^{20}$ (1997) suggested acid conditioning as an effective way to obtain higher bond strength, because in this process only inorganic components are taken away and collagen fibrils become exposed for micromechanical support.

Air abrasion did not produce adequate adhesive force and its association with acid conditioning led to a reduction in bond strength. These results are not in accordance with some previously published studies ${ }^{5,12,14}$, which reported no difference between the use of adhesive techniques on abraded dentin with or without acid conditioning, and good results using both techniques. In these studies, the good performance of air abrasion is attributed to an increase in tooth surface roughness when it is applied; thus, the use of adhesive systems is not necessary because the surface is retentive.

Nakabayashi, Saimi ${ }^{17}$ (1996) stated that the increase in smear layer amount during structure preparation reduced adhesive system effectiveness. Air abrasion shows low smear layer formation when compared to diamond burs ${ }^{10}$, thus adhesive systems' penetration would be more effective 
Leite FRM, Capote TSO, Zuanon ACC. Application of the total etching technique or self-etching primers on primary teeth after air abrasion. Braz Oral Res 2005;19(3):198-202.

on air abraded surfaces and the hybrid layer formation would be improved. They also suggested that the good results for air abrasion and adhesive system association were due to the enlargement of the area caused by the impact of aluminum oxide particles and the higher dentin roughness. Both facts could reduce interfacial gap formation between composite and dentin.

This study showed that the use of 37\% phosphoric acid prior to the application of Scotchbond MP plus on abraded dentin generates low bonding strength. This can be explained by the acid action on abraded dentin that contains reduced smear layer amount ${ }^{10}$. Considering critical the mineral content in primary teeth ${ }^{24}$, and consequently in smear layer, the demineralization caused by this acid was excessive. Possibly, two things could have happened: the collagen collapse and the calcium phosphate crystal deposition on dental surface, both disturbing adhesive systems' penetration ${ }^{21,22}$. Some authors suggested that acid conditioning on primary teeth for excessive time could create fragile areas in the base of the hybrid layer ${ }^{18}$. These factors could explain the low bond strengths found in group 4.

Primary teeth show lower bond strength when compared with permanent dentition due to the reduced inter- and peritubular dentin amount they present ${ }^{24}$. In deciduous teeth, acid conditioning removes solid dentin used for adhesion.

The use of self-etching primers in this study showed high bond strength in comparison with the groups in which phosphoric acid was used. This result must be related to the weak acid present in the composition of self-etching primers, which might have conserved the collagen fibers. Milia et

\section{REFERENCES}

1. Black RB. Technique for nonmechanical preparation of cavities and prophylaxis. J Am Dent Assoc 1945;32:955-65.

2. Brockmann S, Scott R, Eick J. The effect of an air-polishing device on tensile bond strength of a dental sealant. Quintessence Int 1989;20:211-6.

3. Buonocore MG. A simple method of increasing the adhesion of acrylic filling materials to enamel surfaces. J Dent Res 1955;34:849-53.

4. Doty WD, Pettey D, Holder R, Phillips S. KCP 2000 enamel etching abilities tested [abstract n.2474]. J Am Dent Assoc 1994;73:411.

5. Eakle WS, Goodis HE, White JM, Do HK. Effect of microabrasion on dentin permeability and bond strength [abstract IADR n.239]. J Dent Res 1994; 73:131.

6. Ferrari M, Cagidiaco MC, Vichi A, Davidson CL. Dentin infiltration by three adhesive systems in clinical and laboratory conditions. Am J Dent 1996;9:240-4. al. ${ }^{16}$ (1999) concluded that the use of self-etching systems prevented morphological alterations in substrate and caused less interference in the bonding process. They also said that the totaletching technique could lead to the collapse and rupture of collagen fibers when dry air was used.

Self-etching primers show uniform dental substrate demineralization and at the same time the primer penetrates into dentin avoiding collagen rupture. These two processes occurring together could result in more adhesive lateral branches, which increase bond strength ${ }^{19}$.

Just like in this study, Perdigão et al. ${ }^{22}$ (1997) found results showing bond strengths similar between the groups treated with $37 \%$ phosphoric acid associated with Scotchbond adhesive or selfetching primer on dentin that had not been submitted to air abrasion. However, no statistically significant differences were found in this study to justify phosphoric acid conditioning after air abrasion $^{23}$.

\section{CONCLUSION}

It was concluded that on air abraded dentin surfaces of primary teeth, in order to obtain higher bond strength, the use of self-etching primers is recommended instead of the total etching technique, in which acid and primer are used separately.

\section{ACKNOWLEDGEMENT}

This study was supported by the National Council for Scientific and Technological development (PIBIC/CNPq), grant \#106991/2002-7.

7. Goldstein RE, Parkins FM. Air-abraded technology: its new role in restorative dentistry. J Am Dent Assoc 1994;125:551-7.

8. Guirguis R, Lee J, Conry J. Microleakage evaluation of restorations prepared with air abrasion. Pediatr Dent 1999;21:311-5.

9. Gwinnett AJ, Tay FR, Pang KM, Wei SHY. Quantitative contribution of the collagen network in dentin hybridization. Am J Dent 1996;9:140-4.

10. Hannig $M$, Femerling $T$. Influence of air-abrasion treatment on the interfacial bond between composite and dentin. Oper Dent 1998;23:258-65.

11. Katora ME, Jubach T, Polimus MM. Airbrasive etching of the enamel surface. Quintessence Int 1981;12:967-8.

12. Keen DS, Von Fraunhofer JA, Parkins FM. Air-abrasive "etching": composite bond strengths [abstract IADR n.238]. J Dent Res 1994;73:131. 
Leite FRM, Capote TSO, Zuanon ACC. Application of the total etching technique or self-etching primers on primary teeth after air abrasion. Braz Oral Res 2005;19(3):198-202.

13. Kotlow LA. New technology in pediatric dentistry. $N$ Y State Dent J 1996;62:26-30.

14. Laurell K, Lord W, Beck M. Kinetic cavity preparation effects on bonding to enamel and dentin [abstract IADR n.1437]. J Dent Res 1993;72:283.

15. Laurell KA, Hess JA. Scanning electron micrographic effects of air-abrasion cavity preparation on human enamel and dentin. Quintessence Int 1995;26:139-44.

16. Milia E, Lallai MR, García-Godoy F. In vivo effect of a selfetching primer on dentin. Am J Dent 1999;12:167-71.

17. Nakabayashi N, Saimi Y. Bonding to intact dentin. J Dent Res 1996;75:1706-15.

18. Nör JE, Feigal RJ, Dennison JB, Edwards CA. Dentin bonding: SEM comparison of the dentin surface in primary and permanent teeth. Pediatr Dent 1997;19:246-52.

19. Ogata M, Harada N, Yamaguchi S, Nakajima M, Pereira PNR, Tagami J. Effects of different burs on dentin bond strengths of self-etching primer bonding systems. Oper Dent 2001;26:375-82.

20. Olsen ME, Bishara SE, Damon P, Jakobsen JR. Comparison of shear bond strength and surface structure between con- ventional acid etching and air-abrasion of human enamel. Am J Orthod Dentofacial Orthop 1997;112:502-6.

21. Pashley DH, Carvalho RM. Dentine permeability and dentine adhesion. J Dent 1997;25:355-72.

22. Perdigão J, Lopes L, Lambrechts P, Leitão J, Van Meerbeek B, Vanherle G. Effects of a self-etching primer on enamel shear bond strengths and SEM morphology. Am J Dent 1997;10:141-6.

23. Pilo R, Cardash HS, Oz-Ari B, Bem-Amar A. Effect of preliminary treatment of the dentin surface on the shear bond strength of resin composite to dentin. Oper Dent 2001;26:569-75.

24. Sumikawa DA, Marshall GW, Gee L, Marshall SJ. Microstructure of primary tooth dentin. Pediatr Dent 1999;21:439-44.

25. Valentino MF, Nathanson D. SEM evaluation of the bonding interface of enamel and dentin prepared with air abrasion [abstract IADR n. 255]. J Dent Res 1997;76:1126.

26. Walshaw PR, McComb D. SEM evaluation of the resindentin interface with proprietary bonding agents in human subjects. J Dent Res 1994;73:1079-87.

Received for publication on Apr 08, 2005

Sent for alterations on Jun 03, 2005

Accepted for publication on Jul 14, 2005 